\title{
New Ways to Break the Ice
}

\section{Emerging Approaches to the Regulation of Navigation in the Northwest Passage}

\author{
Scott Davidson
}

\section{$1 \quad$ Introduction}

The reduction in sea ice cover of the Arctic as a result of global warming has increased the potential for higher levels of commercial navigation through the Northwest Passage (NWP). This potential creates new frontiers both physically and in the law of the sea by making navigation possible in areas that were previously considered impassable by the vast majority of vessels. The reasons why such navigation may be desirable include: reduction of passage times between the Atlantic and Pacific Oceans with the attendant possibility of cost savings; transportation of exploited mineral resources extracted from the coastal States' littoral areas; marine scientific and hydrographical research; fishing and destination tourism. The focus of this chapter is on the extent of navigational freedoms in the NWP and the minimization of risk to people and the environment in the exercise of such freedoms. The main risks connected with a more extensive use of the NWP routes for navigation include: environmental damage, particularly to highly sensitive ecosystems; negative impacts on indigenous communities, including so-called 'extinction tourism'; ; and dangers to both seafarers and seaborne passengers in this remote and climatically hostile area.

The complex matrix of issues, interests and actors that are evident in any attempt to regulate navigation in the NWP demonstrates that the components of the legal regulation of emerging and fluid frontiers, wherever they may be found, are never quite as straightforward as they may appear at first sight. While the interested actors will usually seek to address the various issues using techniques that they are familiar with, nonetheless, the multi-layered problems associated with what is in fact not a single frontier but multiple,

1 See, for example, H Lemelin, J Dawson and EJ Stewart (eds), Last chance tourism: Adapting tourism opportunities in a changing world (London, Routledge, 2013). 
differentiated frontiers call for multilateral solutions. This can be exemplified by the approach of the polar littoral States, Canada and the United States, which have sought to address the immediate risks of NWP transit by adopting what might be termed traditional positions under existing legal frameworks. Both States agree that the 1982 United Nations Convention on the Law of the Sea (LOSC $)^{2}$ provides the appropriate legal framework for resolving disputed maritime claims and the regulation of shipping and navigation in the NWP, but the oppositional positions taken by the United States and Canada, both of which are arguable because of the open-textured nature of the relevant LOSC norms, have cast the matter as a bilateral dispute which is susceptible only to a zero sum outcome or, more likely in this context, a protracted period of unresolved claim and counterclaim. ${ }^{3}$ As noted above, however, navigational uses of the NWP are not only a matter of regional concern, since all flag States have an interest in the potential use of this sea route. The Losc therefore provides not only the appropriate legal rules for resolving the immediate bilateral dispute between Canada and the United States, but it also provides the normative framework for the resolution of the interests of other actors.

In this regard, it can be observed that States are not the only actors who have an interest in the effective regulation of commercial navigation in the NWP. Ship owners and operators, insurers, seafarers, passengers, coastal communities and indigenous peoples are among the other groups that are actually or potentially concerned with such regulation. Just as the LOSC provides a basic regulatory framework for States, there is also a public international maritime law framework that deals in a more or less comprehensive and detailed way with the regulation of seaborne activity. This framework is predominantly the product of the UN's specialized agency, the International Maritime Organization (IMO) which has created an interlocking system of instruments and guidelines, mainly under the auspices of the International Convention for the Safety of Life as Sea (SOLAS) $1974^{4}$ with input on maritime labour standards from the International Labour Organization's (ILO) Maritime Labour Convention 2006. ${ }^{5}$ The International Code for Ships Operating in Polar Waters (Polar Code), ${ }^{6}$ which came into force on 1 January 2017, is the culmination of the IMo's work to supplement and enhance existing instruments 'to increase the safety of ships' operation and mitigate the impact on the people and

21833 UNTS 3 (LOSC).

3 On the various legal claims by Canada and the United States see below at 251-255.

41184 UNTS 2.

52952 UNTS 3.

6 Adopted 15 May 2015, IMo Doc MEPC 68/21/Add.1, Annex 10 (5 June 2015), 3. 
environment in the remote, vulnerable and potentially harsh polar waters. ${ }^{7}$ The IM O's work is also supported by a number of cooperative initiatives undertaken by the Arctic Council that have resulted in agreements and guidelines. ${ }^{8}$ Among the most relevant and important of these are the Agreement on Cooperation on Marine Oil Pollution Preparedness and Response in the Arctic $2013^{9}$ and the Agreement on Cooperation and Aeronautical and Maritime Search and Rescue in the Arctic 2011. ${ }^{10}$ This multilateral, cooperative approach involving diverse actors sits in sharp contrast to the underlying disputes between the littoral and, potentially, third States. ${ }^{11}$ While the Polar Code and other instruments have a wider scope ratione territoriae than the NWP, nonetheless they provide a means for mediating and reducing potential conflict through shared common standards that serve to minimise risk and, for Canada in particular, the dangers of environmental and ecological damage.

The Northwest Passage is in many respects a long-standing frontier, with icecovered Arctic waters a barrier to potentially lucrative shipping routes for generations. Although the indigenous peoples of the north have navigated Arctic waters since time immemorial, it is with the chronicling of various European attempts to find a northern route between the Atlantic and Pacific Oceans, which avoided Cape Horn, that the issue entered popular Western consciousness. In 1778, Captain James Cook attempted the north-eastern route from the Pacific but found his way blocked by ice. ${ }^{12}$ Although Sir John Franklin's attempt to navigate the NWP from the Atlantic was a heroic failure, the subsequent rescue mission nonetheless established the feasibility of a sea route from the Atlantic to the Pacific. ${ }^{13}$ Roald Amundsen made the first complete transit of the NWP in 1906, despite having to winter over, ${ }^{14}$ but it was not until four

\footnotetext{
$7 \quad$ Polar Code, ibid preamble, recital 1.

8 The nature and work of the Arctic Council is considered below 26o-261.

$9 \quad$ Adopted 15 May 2013, CTS 2013/6.

$10 \quad$ Adopted 12 May 2011, (2O11) 50 ILM 1119.

11 The European Union, for example, has also protested against Canada's adoption of a straight baseline system around its northern offshore archipelago. See below 253.

12 On Cook's attempts to find the NWP, see R Hough, Captain James Cook: A Biography (Coronet, 1995) 339-40; J Robson, 'Northwest Passage' in J Robson (ed), The Captain Cook Encyclopedia (Random House NZ, 2004) 166-168.

13 For a rumbustious yet informative account of the various nineteenth century attempts to find the NWP, see F Fleming, Barrow's Boys (Granta, 1998).

14 R Amundsen, My Life as an Explorer (Thimble Press, 1995).
} 
decades later that a number of specialist vessels, such as icebreakers, made a single season continuous transit of the NWP. ${ }^{15}$ It was, however, the voyage of the US flagged tanker, the ss Manhattan, in 1969 that established the viability of the NWP for commercial navigation during summer months. ${ }^{16}$ Since the voyage of the ss Manhattan, the number of commercial voyages of various kinds has increased. Some of these have been complete passages, but the number of specific destination passages in the Arctic has increased dramatically as ice cover has progressively thinned or disappeared over recent decades. ${ }^{17}$

\section{Decreasing Sea Ice and the Possibility of Increased Commercial Traffic in the NWP}

Although it is usual to talk of 'the NWP', there are in fact a number of navigable routes through the Canadian Arctic Archipelago. All these routes have their challenges. First, they are currently only ice-free during the summer months (normally July-October) and even then, old ice, pack ice, bergy bits and growlers can pose major hazards to even appropriately constructed vessels. ${ }^{18}$ Second, the various routes are not suitable for all vessel sizes. The Amundsen Gulf to Lancaster Sound route, for example, is limited to vessels with a maximum draft of 10 metres. ${ }^{19}$ Third, the hydrography of the NWP is by no means complete, and with thousands of islands, reefs and shifting sandbanks to negotiate, the potential speed of transit is potentially much reduced. ${ }^{20}$ Finally,

15 This was by the Canadian vessel, St Roch, in 1942. See G Kenney, 'Henry Larsen and the St Roch' (Historica Canada), https://www.thecanadianencyclopedia.com/en/article/henrylarsen-and-the-ist-rochi-feature/; accessed 4 July 2018.

16 RA Coen, Breaking Ice for Arctic Oil: The Epic Voyage of the SS Manhattan through the Northwest Passage (University of Alaska Press, 2012). The SS Manhattan carried only one symbolic barrel of crude oil.

17 For a full record of transit passages, see RK Headland et al., 'Transits of The Northwest Passage to End of the 2019 Navigation Season Atlantic Ocean $\leftrightarrow$ Arctic Ocean $\leftrightarrow$ Pacific Ocean', revised 17 March 2020, Scott Polar Research Institute, University of Cambridge, https://www.spri.cam.ac.uk/resources/infosheets/northwestpassage.pdf; accessed 6 October 2020.

18 For a description of the various ice types see World Meteorological Organization Global Cryosphere Watch, 'Cryosphere Glossary', http://globalcryospherewatch.org/reference/ glossary.php; accessed 5 October 2020.

19 Arctic Council, 'Table 2.3 Water Routes of the Northwest Passage' in Arctic Marine Shipping Assessment 2009 Report (AMSA) (Arctic Council, 2009) 21.

$20 \quad$ F Lasserre and S Pelletier, 'Polar Super Seaways? Maritime Transport in the Arctic: An Analysis of Shipowners' Intentions' (2011) 19 Journal of Transport Geography $1465-1473,1466$. 
meteorological information in the high northern latitudes remains unreliable. ${ }^{21}$ All this tends to highlight the point identified in the introduction to this chapter that while it might be convenient to think of boundaries as undifferentiated spaces, they are, in fact, highly differentiated and highly complex, particularly when they are new and emerging. This, in turn, demands more complex, or at least nuanced, solutions.

What has made commercial vessel operators begin to contemplate using the NWP more regularly as an alternative to the Panama Canal route is the year-on-year decrease in ice cover. This has been a noticeable phenomenon since the 1950 and in January 2020 , the ice cover was much reduced on previous years. In October 2020, the US National Snow and Ice Data Center reported that satellite recorded sea-ice was at its fifth lowest level in the 42 year history of recording, and that sea ice extent was significantly below the 1981 to 2010 average. ${ }^{22}$ Air temperatures also remained around 5 degrees Celsius above the $1981-2010$ average. ${ }^{23}$ It is estimated that if global warming and ice melt continues at current rates, the NWP will be ice free all year round by $2050 .{ }^{24}$

Commercial Rationale for the Utilization of the NWP and Potential Impact

The main commercial driver for use of the NWP for navigation is the reduction in distance and thus, potentially, voyage times between the Atlantic and Pacific. A reduction in the length of transit has a number of, theoretically at this stage, commercial benefits for ship owners and their clients. Lasserre and Pelletier point out, for example, that a voyage between London and Yokohama via the NWP is approximately 5,000 and 8,000 kilometres shorter than the Suez and Panama Canal routes respectively. ${ }^{25}$ This, again theoretically, would indicate significant fuel savings and the possibility of more voyages a year. It would also provide a saving on the significant canal transit dues for large vessels. Set against these potential positives are some considerable negatives. These include the increased initial capital investment required to construct A1

21 Ibid.

22 US National Snow \& Ice Data Center, 'That's a wrap: A look back at 2019 and the past decade' ( 7 January 2020), http://nsidc.org/arcticseaicenews/; accessed 6 October 2020.

23 Ibid.

24 Ibid.

25 Lasserre and Pelletier, above (n 20) 1465; see also S Somanathan, P Flynn and J Szymanski, 'The Northwest Passage: A Simulation' (2009) 43 Transportation Research Part A, 127-135. 
category vessels suitable for Arctic navigation; the higher standards of equipment to cope with the Arctic environment; additional training costs for officers and crew; the fact that the NWP is at present only open for navigation during the summer months; the reduced speeds at which vessels are required to travel as a result of uncertain ice conditions; the absence of reliable hydrographic data and the consequent increase in insurance premiums that are payable on vessels seeking to navigate in the NWP. ${ }^{26}$ As a consequence of all these limiting factors, it is clear that commercial cargo operators do not yet see significant advantages in using the NWP as a regular alternative route to the interoceanic canals. $^{27}$

Full transit of the NWP between the Atlantic to the Pacific is not the only navigational option in the Canadian and US Arctic, and it is destination traffic that is set to see the largest growth. ${ }^{28}$ Destination traffic is of various kinds. With thinning ice in the Arctic generally, natural resource exploitation, both mineral and fisheries, is likely to increase with the consequent demand for shore-based handling facilities if not ports. Ports in the Arctic, where they do exist, tend to be small and designed to serve local communities. Until now, Churchill has been the largest NWP port, but the Canadian province of Nunavut has begun construction of a new deep water port in Iqaluit (the territory's capital city on Baffin Island) at the entrance to the NWP with significant funding from the Canadian federal government. ${ }^{29}$ The development of Arctic ports will not only facilitate resource exploitation, but will also help service and make coastal communities more accessible. It is argued that this latter will produce disadvantages as well as advantages. While it will offer the opportunity to supply these communities more economically by using sea rather than air, it also has the potential to open up new areas up for destination tourism, particularly by mega-cruise liners. Disgorging thousands of visitors and their waste into remote indigenous communities might be economically beneficial, but it has also been termed 'extinction tourism' because of the deleterious impact it will have on indigenous peoples and their environment. ${ }^{30}$

\footnotetext{
26 Lasserre and Pelletier, above (n 20) 1466.

27 Ibid $1466-1467$.

28 Ibid $1467-68$.

29 'Ottawa Announces \$64M for Deepwater Port in Iqaluit' iPolitics (30 July 2015), http:// ipolitics.ca/2015/o7/3o/ottawa-announces-64m-for-deepwater-port-in-iqaluit/; accessed 4 July 2018.

30 'Inuit Fear They Will Be Overwhelmed as 'Extinction Tourism' Descends on Arctic' The Observer (21 August 2016), quoting Professor Michael Byers of the University of British Columbia, https://www.theguardian.com/world/2016/aug/20/inuit-arctic-ecosystemextinction-tourism-crystal-serenity; accessed 4 July 2018.
} 
Indigenous communities themselves struggle with issues such as waste disposal, and therefore they are currently unable to service the variety of waste from mega-liners. ${ }^{31}$

Whether use of the NWP is for the purposes of transit or destination, it is clear that the environmental and ecological impacts on the more or less pristine environment of the Arctic are potentially significant. In addition to the usual environmental and ecological threats through accidental discharge to more serious events such as groundings and sinkings, there is also the impact of atmospheric emissions to be considered. ${ }^{32}$ While vessels of various kinds may be the sources of such actual and potential impacts, it is cruise ships which pose major threats to the very environment which their passengers have come to see and experience. Such vessels generate significant amounts of grey water and sewage, as well as producing greenhouse and other noxious gas emissions which, ironically, have created the opportunities through global warming for vessels to navigate the NWP, but which will lead to the ultimate destruction of the special nature of the environment. ${ }^{33}$ Ecological damage may also ensue in a variety of ways through the introduction of new invasive species via bilge water and hull-fouling, and the negative effects on marine mammals and other vertebrates of amplified sub-ice noise pollution and vessel strikes. ${ }^{34}$ Of great concern is the effects on coastal communities and the wider environment that a catastrophic accident such as a grounding or a sinking which releases heavy oil or other toxic substances into the environment. Nearly thirty years after the Exxon Valdez incident, the effects are still being felt, particularly in the failure of a number of species to recover fully from the event. ${ }^{35}$ It is here also that the remoteness of the NWP and the US and Canadian Arctic is relevant as it would take considerable time for both search and rescue and clean-up vessels and aircraft to reach potentially affected areas. ${ }^{36}$

\footnotetext{
31 Ibid.

32 The main ship source emissions are carbon dioxide, nitrogen oxides, sulphur oxides, black carbon and ozone. See AMSA, above (n 19), 140-143.

33 E Eijgelaar, C Thaper and P Peeters, 'Antarctic Cruise Tourism: The Paradoxes of Ambassadorship, "Last Chance Tourism" and Greenhouse Gas Emissions' (2010) 18 Journal of Sustainable Tourism 337-354.

34 AMSA, above (n 19) 145-151.

35 CH Peterson, SD Rice, JW Short et al., 'Long-Term Ecosystem Response to the Exxon Valdez Oil Spill' (2003) 302 Science 2082-2086.

36 'Incident Response and Capacity', AMSA, above (n 19), 168-187.
} 
The potential navigability for commercial purposes of the NWP presents the international law of the sea with new frontiers somewhat paradoxically through the removal of physical barriers to maritime activity. This requires examination of how existing rules can be applied to new circumstances; whether new rules need to be created for novel and evolving circumstances or whether new demands can be satisfied by a combination of both. ${ }^{37}$ The teleological function of legal regulation here is important as consensus about the overarching objectives for the NWP is essential to the design of the current and emerging legal regime and general systems of governance and oversight. The major interests of States and other actors identified in the Introduction are critical to this process. While a number of these interests will be addressed by the application of the norms represented by the LosC, it is recognized within the Convention itself that these alone will not satisfy the interests of all relevant actors and that the parallel development and intersection of other legal frameworks are required to provide a normative matrix and system of legal governance that will yield workable and durable solutions. ${ }^{38}$ Part of the reason for this is that some of the norms and, indeed, legal mechanisms contained in the LOSC are themselves differentiated. An example of this proposition, referred to by David Freestone as 'unfinished agendas', are the provisions for the adoption of further rules in certain areas, such as transboundary fishing. ${ }^{39}$

Turning first to the application of the provisions of the LOSC that broadly refer to ocean space jurisdiction, there is agreement between the United States (which is still not party to the Convention) and Canada that the norms represented by the LOSC are applicable to disputes between them. ${ }^{40}$ The disputes relating to the NWP can be stated relatively simply. Canada maintains

37 It is worth observing that when the Losc was being negotiated, and at the time of its adoption in 1982, the prospect of global warming and its effects on the polar regions was little understood, and certainly not within contemplation of the drafters, so the norms adopted were not specifically designed to address this situation.

38 For an overview, see L Boone, 'International Regulation of Polar Shipping' in EJ Molenaar, AG Oude Elferink and DR Rothwell (eds), The Law of the Sea and the Polar Regions. Interactions between Global and Regional regimes (Brill, 2013) 193-215; see also EJ Molenaar, 'Arctic Marine Shipping: Overview of the International Legal Framework: Gaps and Options' (2009) 18 Journal of Transnational Law and Policy 289-316.

39 D Freestone, 'The Effective Conservation and Management of High Seas Living Resources' (1994) 5 The Canterbury Law Review 341-363.

40 J Kraska, 'The Law of the Sea Convention and the Northwest Passage' (2007) 22 International Journal of Coastal and Marine Law 257-282, 269-270. 
that the waters of the NWP are internal waters either by the application of the provisions relating to historic waters or, alternatively, the application of a straight baseline system in accordance with Article 7 of the LOsc. If either of these approaches prevailed, Canada would exercise full sovereignty over these waters, subject to the exception contained in Article 8. Côté and Dufresne have noted that these two claims have been analysed extensively and that the historic title claim is generally viewed as the weaker of the two. They note that the straight baseline claim 'is thought to be better and strong enough in international law'.11 It is proposed therefore to focus here on this latter claim. ${ }^{42}$

Article 7 of the LOSC, which is itself a codification of the ICJ's decision in the Anglo-Norwegian Fisheries Case, ${ }^{43}$ contains the law governing the application of straight baselines. It provides:

In localities where the coastline is deeply indented and cut into, or if there is a fringe of islands along the coast in its immediate vicinity, the method of straight baselines joining appropriate points may be employed in drawing the baseline from which the breadth of the territorial sea is measured.

The essential elements of Article 7 and their application have been rehearsed at length elsewhere, ${ }^{44}$ but it would seem on any objective assessment that Canada's Arctic coast is fringed by islands that would justify the use of straight baselines. ${ }^{45}$ It would also appear that the straight baselines, which are marked on official Canadian charts, conform to the requirements of Article 7(3), which stipulate that they must not depart to any appreciable extent from the general direction of the coast, and the sea areas lying within the lines must be sufficiently closely linked to the land domain to be subject to the regime of internal waters. Taking this requirement into account, it is arguable that the seasonal ice-bound nature of the environment strengthens rather than weakens this

$41 \quad$ F Côté and R Dufresne, 'The Arctic: Canada's Legal Claims', Infoseries, Parliament of Canada, 24 October 2008.

42 Kraska analyses both claims in detail. See above ( $\mathrm{n} 4 \mathrm{O})$.

43 United Kingdom v Norway, Order, (1951) ICJ Reports, p 8.

44 RR Churchill and AV Lowe, The Law of the Sea (3rd ed, Manchester University Press, 1999) 106; see also JA Roach and RW Smith, United States Responses to Excessive Maritime Claims (2nd ed, Nijhoff, 1996) 339ff; TL McDorman, 'In the Wake of the Polar Sea: Canadian Jurisdiction and the Northwest Passage' (1986) 10 Marine Policy 243-257.

45 This is not a view shared by Kraska who states that the Canadian baselines 'project at numerous points tens of miles into the high seas, thus virtually violating every rule governing lawfully drawn baselines'. Kraska, above (n 40) 272 (emphasis added). 
link. The application of straight baselines is however subject to the limitation of Article 8(2) of the LOSC. This provides that where the establishment of straight baselines has the effect of enclosing as internal waters areas which had not previously been considered as such, a right of innocent passage continues to exist in those waters. In practice this would mean that foreign-flagged vessels could continue to navigate through the NWP, but would potentially be subject to the extensive controls that Canada as the coastal State could impose on a non-discriminatory basis on such vessels, including the prescription of sea-lanes, traffic separation schemes and charges for services such as pilotage and ice-breaking. ${ }^{46}$

Because of the restrictions imposed on navigation by the characterization of NWP waters as internal, the United States and the European Union take the position that the various routes through the NWP should be considered as straits used for international navigation that are governed by the rules in Part III of the LOSC. ${ }^{47}$ The fundamental difference here is that the non-suspensible right of transit passage limits the ability of the coastal State to regulate activities in the same way that it might in cases of innocent passage, although it can still prescribe sea-lanes and traffic separation schemes. Indeed, Canada already prescribes shipping routes in the NWP and imposes a number of reporting requirements under its Arctic Waters Pollution Prevention Act and regulations adopted thereunder. ${ }^{48}$

If a straight baseline system applied to the outer islands of the Canadian Arctic Archipelago were accepted, it would project the outer limit of Canada's territorial sea and exclusive economic zone to a much greater distance into the Arctic Ocean. While this is not directly associated with commercial navigation through the NWP, it does have implications for Article 234 of the LOSC, the socalled 'Arctic Exception', which provides:

Coastal States have the right to adopt and enforce non-discriminatory laws and regulations for the prevention, reduction and control of marine pollution from vessels in ice-covered areas within the limits of the exclusive economic zone, where particularly severe climatic conditions

46 See LosC, above (n 2), Arts 18-21. For commentary, see Churchill and Lowe, above (n 44), 209-214.

47 D Pharand, Canada's Arctic Waters in International Law (Cambridge University Press, 1988) 251; Kraska, above (n ), 265.

48 RSC, 1985, c A-12. On the European Union's position, see R Churchill, 'The European Union as an Actor in the Law of the Sea, with Particular Reference to the Arctic' (2018) 33 International Journal of Coastal and Marine Law 290-323, 307. 
and the presence of ice covering such areas for most of the year create obstructions or exceptional hazards to navigation, and pollution of the marine environment could cause major harm to or irreversible disturbance of the ecological balance. Such laws and regulations shall have due regard to navigation and the protection and preservation of the marine environment based on the best available scientific evidence.

This provision was included in the LOSC at the behest of three Arctic States, namely, Canada, Russia and the United States, as a means of offering enhanced jurisdiction to protect the environment from vessel source pollution. Bartenstein has subjected the provision and its origins to comprehensive analysis, identifying particular problems with its interpretation relative to its application rationes territoriae, materiae and temporis. Many of the difficulties stem from the lack of precision of the terms used, and these are not ameliorated because of the absence of reliable travaux préparatoires. ${ }^{49}$ As a result, Bartenstein argues that the underlying rationale of Article 234 is also flawed in that it promotes unilateral action at the expense of multilateralism, which, she says, 'enjoys greater legitimacy'. ${ }^{0}$ Her ultimate conclusion is that 'the numerous interpretational uncertainties are an obstacle to a clear contribution to safer navigation in the Arctic..51 It would thus seem to add little practical value to the regulation of navigation in the NWP as ice cover continues to decrease at a progressively faster rate.

While a preliminary assessment of the international law of the sea framework for regulation of navigation in the NWP suggests that it may too blunt an instrument to meet all interested parties' needs and aspirations, nonetheless, Jensen has suggested that the Polar Code may be regarded as the product of a 'rule of reference' in the LOsC through which the norms in the Code assume the status of generally accepted international rules and standards. ${ }^{52} \mathrm{He}$ concludes, however, that the practice required for this may not yet be sufficiently

49 K Bartenstein, "The "Arctic Exception" in the Law of the Sea Convention: A Contribution to Safer Navigation in the Northwest Passage?' (2011) 42 Ocean Development and International Law 22-52; see also Boone, above (n 38), 195-196 who supports this view.

50 Bartenstein, above (n 49), 46.

$51 \quad$ Ibid 45 .

$5^{2} \emptyset$ Jensen, 'The International Code for Ships Operating in Polar Waters: Finalization, Adoption and Law of the Sea Implications' (2016) 7(1) Arctic Review on Law and Politics 6o-82, 71-71. On the rule of reference principle, see International Law Association, Report of the London Conference (200o) by the Committee on Coastal State Jurisdiction Relating to Marine Pollution, 32, the Report is available on the ILA Committee website, http://www. ila-hq.org/; accessed 4 July 2018. 
extensive to reach such a conclusion in the case of the Polar Code. ${ }^{53}$ Similarly, even if the existing dispute between the United States and Canada were settled amicably, it is unlikely to produce an outcome that meets the wider concerns of the various interested parties in securing safe navigation and the concomitant requirements of the protection of the environment and human integrity. The next section is therefore devoted to considering alternative approaches, which, while not seeking to restrict Canada's claims to sovereignty, may nonetheless provide more workable and widely accepted multilateral solutions that will also satisfy the future interests of flag States and other interested parties.

\section{Safety of Navigation in the NWP}

As noted in the Introduction, the adoption of the Polar Code in January 2017 represents a major advance in the regulation of shipping in polar waters. Its comprehensive nature is recognized in its Preamble which refers not only to the safety of shipping but also the protection of the people and the marine environment in remote, vulnerable and harsh polar waters. In order to gauge the likely impact of the Code on navigation through the NWP routes, it is necessary to give a short overview of its contents. Before doing so, it is worth noting that part of the Code's novelty is that it is designed to operate on a risk-based approach which seeks to identify and then reduce risk holistically. There may be lessons here for other emerging frontiers where boundaries are uncertain and fluid but in need of regulation. While avoidance of uncertainty is desirable in any form of normative system, it cannot always be avoided, and risk management may be one of the most feasible ways forward.

The Polar Code, which was negotiated under the auspices of the IMO, is effectively a series of addenda to a number of existing instruments, including SOLAS and MARPOL. ${ }^{54}$ The Code comprises two parts, both of which contain mandatory and recommendatory sections that are based on the foundational

\footnotetext{
53 Jensen, above (n 52$), 77-78$.

54 The affected instruments include solas above (n 4), as amended by Imo Resolution MSC.386(94), 21 November 2014, effective 1 January 2017; the 1973 International Convention for the Prevention of Pollution from Ships (MARPOL), (as amended to Annexes I, II, IV and v, Imo Resolution MEPC.265(68), 15 May 2015), 1340 UnTs 61; the 1966 Load Lines Convention, 640 UNTS 133; the 1972 Collision Regulations (COLREGS), 1050 UNTS 16; the 1978 International Convention on Standards and Training, Certification and Watchkeeping for Seafarers (STWC), 1361 UNTS 19o; and the 1979 International Convention on Maritime Search and Rescue Convention, 1405 UNTS 97. For the background to the negotiation of the Polar Code, see Boone, above (n 38 ), passim.
} 
international legal instruments. ${ }^{55}$ As Jensen suggests, this mix of normative and goals orientated approaches provides the necessary certainty coupled with flexibility to accommodate the different capacities and interests of the various parties. As he notes:

Highlighting overall goals and purposive considerations in an interpretation of the Code's descriptive characteristics may give greater room for maneuver for national authorities to fulfill their obligations under the Code; admitting a broad "margin of appreciation" provides certain flexibility and may even permit interference with the prescriptive regulations. Power of discretion, however, does not necessarily imply a lower standard of protection. In the long run, it may also result in stricter standards. ${ }^{56}$

Part I-A covers safety measures in general under solas and other relevant international maritime instruments; while Part II-A deals with pollution prevention measures. These are the mandatory parts of the Code; their equivalent Part B elements contain recommendations. As the Code is built on the foundations of existing international instruments, there are some basic criteria that apply, including ship type and size. The Code will thus apply to internationally registered cargo vessels of over 400 gross tonnes and vessels carrying more than 12 passengers in respect of safety measures and to a broader class of vessels regarding control of pollution under MARPOL and its various Annexes. ${ }^{57}$

Key to polar operations are the suitability of vessels to operate in Arctic waters. The Code requires that ships intending to operate in the Arctic must be issued with a Polar Ship Certificate. ${ }^{58}$ Such a certificate is issued following a survey by a flag State or a classification society that classifies vessels from Polar Category A to C. Category A ships are designed as a minimum for operation in polar waters in medium first-year ice, which may contain old ice inclusions; Category B ships are designed for operation in polar waters in at least thin firstyear ice, which may include old ice inclusions and Category $C$ ship are those designed to operate in open water or in ice conditions less severe than those included in Categories A and B. 59

55 Polar Code, above (n 6), Art 4.

$5^{6}$ Jensen, above ( $\left.\mathrm{n}_{52}\right)$, section 4 .

57 MARPOL, above (n 55$)$. International Maritime Organization, Amendments to MARPOL Annexes I, II, IV and v (to make use of environment-related provisions of the Polar Code mandatory), IMO Resolution MEPC.265(68) (15 May 2015, effective 1 January 2017).

$5^{8} \quad$ Polar Code, above (n 6), Part I-A, chapter 1, para 1.3.1.

59 Ibid Art 2.1-2.3. 
Ships' equipment and installations must also be fit for purpose, given the harsh environmental conditions under which they must operate. ${ }^{60}$ These include all intakes and exhausts, particularly for fire-fighting, since fire at sea is one of the most dangerous events that can occur, and extremely low temperatures will hinder the effectiveness of nearly all extinguishants. ${ }^{61}$ External protrusions on vessels such as booms, masts and sails that may accumulate ice and make them top heavy and thus susceptible to capsize are also required to be limited in construction. ${ }^{62}$ The regulation of life-saving equipment to protect people in the event of ship evacuation is key to the Polar Code's requirements and is set at the high standard that would be expected to maximize survival of crew and passengers in the harsh polar environment. ${ }^{63}$

While ensuring that vessels and their equipment intended for polar operations are set at an appropriate standard, the human element in operating ships in the Arctic region is also addressed by the Code. Given the hostile environment in which vessels and personnel must operate, it is clear that both officers and men must not only be suitably trained, but also provided with the necessary equipment to protect their physical integrity and health. ${ }^{64}$ The goal of the Code itself is to ensure that ships operating in polar waters are appropriately manned by adequately qualified, trained and experienced personnel. In order to address this, training and certification for crew are much enhanced by the Code through significant amendment to the International Convention on Standards and Training, Certification and Watchkeeping for Seafarers. ${ }^{65}$

The Code's enhancement of pollution prevention measures builds upon the requirements of MARPOL, which already contain a number of provisions dealing with the regulation of marine pollution in the polar regions. The Code's additional provisions are therefore enhancements to these which develop the annexes that deal with six different forms of pollution. In the area of pollution by oil, oily mixtures and noxious liquid substances, there is an absolute prohibition on any discharge. ${ }^{66}$ The discharge of sewage and garbage is also prohibited save for when it is in either comminuted or disinfected form, in which case the distance from which it can be discharged is in increased to a

\footnotetext{
6o Ibid Part 1-A, chapters 6-7.

61 Ibid Part 1-A, chapter 3 (on general structural design) and chapter 7 (on fire safety/ protection).

62 Ibid Part I-A, chapter 4.

63 Ibid Part I-A chapter 8.

64 See also the Additional Guidance to Chapter 8 of the Polar Code, ibid, which identifies samples of equipment which should be carried.

65 Ibid Part I-A, chapter 12.

66 Ibid Part II-A, chapter 1, para 1.1.
} 
distance of more than 3 nautical miles from any ice-shelf, fast ice or areas of ice concentration exceeding 1/10. ${ }^{67}$ Untreated sewage may only be discharged at a distance of 12 nautical miles from such ice features. ${ }^{68}$ All category A and B ships and passenger ships constructed after 1 January 2017 are not permitted to discharge sewage at all, unless they have an approved sewage treatment plant in operation. ${ }^{69}$ With the increasing numbers of mega-cruise ships visiting the Arctic, generating thousands of tonnes of sewage, grey water and garbage, these become increasingly important provisions.

A significant feature of the Code is that all ships operating in the Arctic waters must carry a Polar Water Operational Manual (PWOM) to provide owners, operators, masters and crews with sufficient information regarding a ship's operational capabilities and limitations in order to support their decisionmaking processes. ${ }^{70}$ Under the regulations contained in this part of the Code, the PWOM is to include, inter alia, risk-based procedures for voyage planning and receiving environmental condition forecasts; addressing the limitations of the available hydrographic, meteorological and navigational information and implementation of special measures to maintain systems confronting extremely low temperatures and to prevent topside icing to prevent instability. ${ }^{71}$ The regulations also provide how emergency situations, including search and rescue, salvage and spill responses will be handled, as well as what procedures are in place to maintain life support and ship integrity in the event of prolonged entrapment by ice. ${ }^{72}$ This risk-based assessment lies at the heart of the Code and introduces the Polar Operational Limit Assessment Risk Indicating System (POLARIS) which was devised after the text of the Code was developed, but which is incorporated into it and takes into account the variables between ice conditions and the types of vessel involved in the navigation. ${ }^{73}$ As noted above, this risk-based approach recognizes the fluidity and variability of the environment and circumstances in managing the application of the Code's normative elements, and may prove a useful model for the management of frontiers elsewhere.

\footnotetext{
67 Ibid Part II-A, chapter 4, para 4.2.1.1.

68 Ibid Part II-A, chapter 4, para 4.2.1.2.

69 Ibid Part II-A, chapter 4, para 4.2.2.

$70 \quad$ Ibid Part I-A, chapter 2.

71 Ibid Part I-A, chapter 2, para 2.3.

72 Ibid Part I-A, chapter 2, paras 2.3.4-2.3.5.

73 MA Stoddard, L Etienne, M Fournier, R Pelot and L Beveridge, 'Making Sense of Arctic Maritime Traffic Using the Polar Operational Limits Assessment Risk Indexing System (POLARIS)' (2016) IOP Conference Series: Earth and Environmental Science 34: 012034 , http://iopscience.iop.org/article/10.1088/1755-1315/34/1/o12034/pdf; accessed 4 July 2018.
} 
Essential to the operation of Polar ship certification and PWOM is the application of port State control. Within an international matrix of memoranda of understanding, States' maritime authorities exercise a systematic ship inspection approach to ensure the application of standards relating to ship safety, pollution, training, ILO labour standards, and so on. The overarching Paris MOU for European States is particularly relevant to Arctic port State control since all the Arctic Council States, apart from the United States which has observer status, are party to it. ${ }^{74}$ Similarly, for the purposes of the NWP, Canada is party to the International Ship and Port Facilities Security (ISPS) Code; the United States is not, but nonetheless has its own regulatory code, which subjects vessels to various conditions, including certificate inspection. ${ }^{75}$ This is one area of operation where existing rules and processes can be shown to accommodate novel issues, although the voluntarist nature of port State control may result in a degree of incoherence and therefore inconsistency in the application of the appropriate norms which may in the longer term be undesirable because of the negative impact that this might have on the overall regime.

While the adoption of the Polar Code is a major step forward in securing the safety of navigation and the protection of the Arctic environment in the NWP, it is nonetheless apparent that with increasing shipping activity it will be necessary to continue to monitor and reinforce progress in this field. Although the basic regulatory framework is now in place, questions of how to exercise Arctic marine governance more effectually still remain. As noted above, much will depend on the ability of the coastal States to exercise the necessary control through port State inspections of certificates, the designation of navigational routes and practical aids to navigation through ice and meteorological forecasting, but an overarching system of regional governance remains desirable both to monitor implementation of international rules and standards and to secure progress in accordance with emerging best practice in all relevant areas.

74 Paris Memorandum of Understanding on Port State Control, adopted 26 January 1982,(1982) 21ILM 1.

75 See United States Coastguard, Port State Control Division (CG-CVC-2), https://www. dco.uscg.mil/Our-Organization/Assistant-Commandant-for-Prevention-Policy-CG-5P/ Inspections-Compliance-CG-5PC-/Commercial-Vessel-Compliance/Foreign-OffshoreCompliance-Division/; accessed 4 July 2018. 
The main fora through which this has been and will continue to be achieved are the IMO and the Arctic Council.

While the status, functions and importance of the IMO as a specialized agency of the United Nations are well-known, those of the Arctic Council are less so. Established by the Ottawa Declaration of 19 September 1996, the Arctic Council is described as a 'high level forum for promoting cooperation, coordination and interaction among the Arctic States, with the involvement of the Arctic indigenous communities and other Arctic inhabitants on common Arctic issues, in particular issues of sustainable development and environmental protection in the Arctic. ${ }^{76}$ It has the mandate of overseeing and coordinating a variety of programmes and working groups including the Arctic Monitoring and Assessment Program (AMAP); Conservation of Arctic Flora and Fauna (CAFF); Protection of the Arctic Marine Environment (PAME); Emergency Prevention, Preparedness and Response (EPPR); Sustainable Development Working Group (sDWG) and the Arctic Contaminants Action Programme (ACAP). ${ }^{77}$ The most significant of its activities in the field of shipping emerged from PAM E. In November 2004 at the Council's Ministerial meeting in Reykjavik, PAME was asked to 'conduct a comprehensive Arctic marine shipping assessment as outlined under the Arctic Marine Strategic Plan: ${ }^{78}$ This resulted in the production of the Arctic Marine Shipping Assessment 2009 Report (AMSA). ${ }^{79}$ The AMSA is not only an important piece of work through gathering a significant amount of information and data about all aspects of Arctic shipping in one place, but because it also makes a number of recommendations regarding, inter alia, the enhancement of Arctic marine safety. It is here that we see the intersection of the Council's activities with those of the

76 Declaration on the Establishment of the Arctic Council, Joint Communique of the Governments of the Arctic Countries on the Establishment of the Arctic Council (Ottawa Declaration), adopted 19 September 1996. The Arctic Council Member States are Canada, Denmark (including Greenland and the Faroe Islands), Finland, Iceland, Norway, the Russian Federation, Sweden, and the United States. Six Arctic indigenous communities have Permanent Participant status and 12 States have observer status. For a general overview and analysis of the creation, development and operation of the Arctic council see B Baker, 'The Developing Regional Regime for the Marine Arctic' in Molenaar, Oude Elferink and Rothwell, above (n 38) 35-59. See also EJ Molenaar, 'Current and Prospective Roles of the Arctic Council System within the Context of the Law of the Sea' (2012) International Journal of Coastal and Marine Law 553-595.

77 See Arctic Council, 'Working Groups', https://arctic-council.org/en/about/workinggroups/; accessed 5 October 2020.

78 AMSA, above (n 19), 2.

79 Ibid. 
IMO and a commitment to harmonization of Arctic shipping governance. In the case of the former, the recommendation is that the Arctic States 'decide to cooperatively support efforts at the [IMO] to strengthen, harmonize and regularly update international standards for vessels operating in the Arctic.80 Indeed, it was noticeable throughout the drafting of the Polar Code that the Arctic Council States were critical to its effective development. ${ }^{81}$ In the case of the latter, the AMSA recommends that the Arctic States should work towards the harmonization of shipping regulatory regimes in a manner consistent with the LOSC. ${ }^{82}$

Subsequent to the approval of the AMSA by the Arctic Council, there have been four biennial implementation status reports in $2011,{ }^{83} 2103,{ }^{84} 2015,{ }^{85}$ and $2017 .{ }^{86}$ Each of these has tracked the status of progress on the recommendations in the original 2009 report. It is through these monitoring reports that it is possible to discern the clear developments and cooperative measures taken by the Arctic States to keep abreast of the challenges of shipping regulation. Indeed, as the 2017 report notes, the adoption of the Polar Code which was achieved with major input from these States 'is the first step to ensure robustness of ship operations in the Arctic waters'. ${ }^{87}$ Despite such a major advance it is apparent that these challenges will not only persist but will also change in response to environmental factors and other imperatives. It is also clear that the Arctic Council through its periodic AMsA reports will keep these challenges and responses to them under constant review.

80 Ibid Recommendation 1(B): Imo Measures for Arctic Shipping. For a full list of the recommendations see http://www.pame.is/index.php/projects/arctic-marine-shipping/amsa; accessed 4 July 2018.

81 Arctic Council, Status on Implementation of the AMSA 2009 Report Recommendations, May $2017,2$.

82 Ibid.

83 Arctic Council, Status on Implementation of the AMSA 2009 Report Recommendations, May 2011.

84 Arctic Council, Status on Implementation of the AMSA 2009 Report Recommendations, May 2013.

85 Arctic Council, Status on Implementation of the AMSA 2009 Report Recommendations, April 2015.

86 Arctic Council, Status on Implementation of the AMSA 2009 Report Recommendations, May 2017.

87 Ibid $2-3$. 
A moment's reflection demonstrates that the potential for commercial navigation through the NWP, while worthy of study in its own right, highlights wider issues for international law and international relations in general. A catalogue of these issues includes, among others, the unforeseen and unforeseeable impacts and challenges of global warming; environmental and ecological damage both actual and potential through increased commercial activities; the impact on human communities (particularly those of indigenous peoples) and the danger to the safety and well-being of people who are exposed either by the necessity of work or the urge for 'exploration' tourism. As the ice in the Arctic continues to thin, and perhaps ultimately disappear, these issues will not only remain but will continue to present both practical and legal challenges of constantly changing new and highly differentiated frontiers. Indeed, as the 'ice frontiers' move or disappear, they are replaced with others as the challenges relating to the safe use of the passage. The Arctic Council recognizes the complexities in predicting these changes, and it is difficult to better its conclusion in its Status on Implementation of the AMSA 2009 Report Recommendations 2015 in which it said:

It is difficult to speculate on how shipping activity in the Arctic Region will evolve, as much of it is influenced not just by potential accessibility resulting from changing environmental conditions, but also by larger geopolitical and commodity market considerations. The evolution of future Arctic Council initiatives and projects to further advance the AMSA recommendations is similarly difficult to predict and will no doubt reflect in part these changing patterns of shipping. ${ }^{88}$

It is also difficult to better the approach to solving these problems as identified by the Arctic Council in its 2017 Report, 'it is only through good international cooperation that we can properly address and find future solutions. ${ }^{89}$ This could well be the motif for resolving the majority of international problems presented by frontiers both old and new.

88 AMSA, above (n 85), 3 .

89 AMSA, above (n 86), 5 . 